\title{
APPLICATION OF A RECENTLY DEVELOPED GEOTECHNICAL CARBON CALCULATOR IN EUROPE
}

\section{APLICAÇÃO DA RECÉM DESENVOLVIDA CARCULADORA DE CARBONO PARA OBRAS GEOTÉCNICAS NA EUROPA}

\author{
Sara Rios ${ }^{1}$ \\ Nuno Cristelo ${ }^{2}$ \\ António Viana da Fonseca ${ }^{3}$ \\ Ivo Rosa ${ }^{4}$ \\ Catarina Ramos ${ }^{5}$
}

\begin{abstract}
Recent research regarding soil stabilization has been increasingly concerned with environmental performance. The present paper applies the newly developed $\mathrm{CO}_{2}(\mathrm{eq})$ geotechnical calculator, created by the European Federation of Foundation Contractors and the The Deep Foundations Institute, to assess the behavior of three different binders used in the construction of cutter-soil mixing columns, which formed an embankment/bridge transition wedge. The binders were based on ordinary Portland cement, on a blast furnace slag and cement blend and alkali activated fly ash. Results show that the last two binders are significantly more effective, in terms of environmental performance, than the more traditional cement-based binder. Although the blast furnace slag cement, at this early stage of the geopolymeric binders, appears as the most interesting option, the fact that the $\mathrm{CO}_{2} /$ cost ratio of both options is very similar stands out.
\end{abstract}

Keywords: Carbon market. Geotechnical engineering. Cement. Fly - ash. Carbon calculator.

\section{RESUMO}

A investigação recente em estabilização de solos, tem mostrado uma preocupação crescente com o desempenho ambiental das soluções desenvolvidas. O presente artigo aplica a recém desenvolvida calculadora de carbono para obras geotécnicas, criada pela European Federation of Foundation Contractors e a The Deep Foundations Institute, para conhecer o desempenho ambiental resultante da utilização de três ligantes na construção de colunas de cutter-soilmixing para formar uma cunha de transição entre um aterro e uma ponte. Os ligantes são:

\footnotetext{
${ }^{1}$ CONSTRUCT-GEO, Faculdade de Engenharia (FEUP), Universidade do Porto, Portugal. Endereço: R. Dr. Roberto Frias s/n, 4200-465 Porto, Portugal. Telefone: +351 22508 1400. E-mail: sara.rios@fe.up.pt.

${ }^{2}$ Department of Civil Engineering, University of Tras-os-Montes e Alto Douro, Portugal. Endereço: Quinta de Prados, 5001-801 Vila Real, Portugal. Telefone: +351 259350000

${ }^{3}$ Faculdade de Engenharia (FEUP), Universidade do Porto, Portugal. Endereço: R. Dr. Roberto Frias s/n, 4200465 Porto, Portugal. Telefone: +351 225081400 .

${ }^{4}$ Teixeira Duarte, S.A, Lisboa, Portugal. Endereço: R. Encosta das Lagoas, 2740-265 Porto Salvo, Oeiras, Portugal. Telefone: +351217912300

${ }^{5}$ Faculdade de Engenharia (FEUP), Universidade do Porto, Portugal. Endereço: R. Dr. Roberto Frias s/n, 4200465 Porto, Portugal. Telefone: +351 225081400 .
} 
cimento Portland convencional, cimento especial com escórias de alto forno, e geopolímeros criados pela ativação alcalina de cinzas volantes. Os resultados mostram que os últimos dois ligantes são significativamente mais eficientes, em termos de desempenho ambiental, do que o cimento Portland tradicional. Embora o cimento com escórias de alto forno se apresente com a opção mais interessante, nesta fase de desenvolvimento dos ligantes geopolimericos, é de salientar o facto da razão $\mathrm{CO}_{2} /$ custo ser muito similar nestas duas opções.

Palavras-chave: Mercado de carbono. Engenharia geotécnica. Cimento. Cinza. Calculadora de carbono

\section{Introduction}

The environmental protection issues are becoming more and more important and European specifications and standards are being stricter which has the necessary implications in the daily work of companies and institutions. The carbon calculator studied in this work aims to encourage the construction industry, namely the geotechnical area, to contribute to the environmental sustainability. The carbon calculator helps companies to do a more conscious choice of constructive solutions, by evaluating the release of greenhouse gases of the different technical activities necessary for their implementation.

The European Federation of Foundation Contractors (EFFC) and The Deep Foundations Institute (DFI) have created a tool to calculate the carbon dioxide emissions of foundation and geotechnical works. It considers all the $\mathrm{CO}_{2}$ sources from materials, energy, transport, equipment mobilization, people transport and waste, being developed using verifiable, standardized data to enable accurate benchmarking of competing project proposals. Prior to its development there existed no single standardized tool for calculating $\mathrm{CO}_{2}$ emissions for these types of ground works. The aim is not only to evaluate the carbon footprint of a work, but also to establish a comparison between various solutions in order to find the best. Unlike other calculators, its parameters and databases have been developed and targeted for special geotechnical works. One of the points assessed by the calculator is the cost, the key issue for making a comparison of emission per unit of cost. This may be an argument that, together with emissions, becomes decisive for both the contractor and the project owner.

This study is of great importance to the construction industry as it prepares the companies for the forthcoming laws and rules limiting carbon emissions. At present, these regulations do not totally cover this sector, but with increasing environmental requirements, the construction industry will be soon affected. The application of the carbon calculator to 
these particular cases not only allowed a better understanding of its operation, but also led to a greater knowledge of the construction methods.

\section{The EFFC/DFI carbon calculator}

Along with all the other carbon footprinting standards, the underlying principle of this calculator consists in the multiplication of activity data by emission factors, as indicated in equation 1. These factors convert the emission associated with each activity into an equivalente amount of carbon dioxide $\left(\mathrm{CO}_{2} \mathrm{eq}\right)$ based on their global warming potential.

$$
\text { Carbon Footprint }=\sum_{i=1}^{n} A_{i} \cdot E F_{i}
$$

where $A_{i}$ is the activity data (e.g., kwh of natural gas, tons of steel, etc...) and $E F_{i}$ is the emission factor (e.g., $\mathrm{CO}_{2} \mathrm{eq} / \mathrm{kwh}$ of natural gas, etc...). Standards and methods often recommend a specific emission factor database, but also recognize the use of other data if considerered more relevant.

During the last years, several carbon calculators were developed by some of the EFFC and DFI members: BAM, Balfour Beatty, Bachy Soletanche carbon Calculator, Keller carbon calculator, Cementation Skanska carbon calculator, Tata Steel/BCSA carbon calculator, UK Environmenal Agency carbon calculator. The calculator developed by Carbone 4 for EFFC and DFI integrates the best pratices identified in these solutions in order to provide an European tool capable to evaluate and compare different foundation projects with credible and structured methodologies accepted internationally. Although international emission factor databases do exist (IPCC, ECOINVENT), the majority of the tools use national databases such as ADEME Bilan Carbone, DEFRA and Sustainable Concrete. EFFC DFI carbon footprinting is based on international sources being therefore a generic database for use across Europe (LEMAIGNAN; WILMOTTE, 2013).

This carbon calculator focused on deep foundation and ground improvement techniques addresses seven different techniques (bored piles, displacement piles, micro piles, diaphragm and slurry walls, sheet pile walls, grouting and soil mixing), although other techniques may be included manually. The emission sources considered in this tool are the following:

- Materials: embodied carbon in materials, due to their manufacturing (cement, steel...)

- Energy: energy consumed on the construction site (grid electricity, diesel, gasoline...) 
- Freight: materials transportation, from factory to construction site (trucks, train, boat...)

- Mob/demob: equipment's transportation

- People's transportation to the construction site

- Assets: equipment's manufacturing (depreciation)

- Waste: waste transportation, from construction site to treatment site and waste treatment

These emission sources are classified into primary or secondary according to relative contribution to the global footprint of the technique: a secondary source represents less than $5 \%$ of the total amount of $\mathrm{CO}_{2} \mathrm{eq}$, while a primary emission source represents at least $5 \%$. Generally, primary emission sources are from materials, energy and freight and represent around $90 \%$ of total carbon footprint. Since secondary emission sources have a minor influence on the total footprint, the carbon calculator provides simplified methods to estimate their contribution. The first method consists in obtaining the secondary emission source as a percentage of the primary emission source. The second method consists in having standardized activity data by assuming a predefined ratio or value that will represent the activity data needed for a secondary emission source. Nevertheless, a refined mode can always be implemented in more detailed approaches if real values are available for the secondary emission sources.

\section{Methodology followed in this work}

In this paper, the carbon calculator was applied to a transition wedge project with cutter soil mixing (CSM) columns. Transition zones between embankments and bridges or viaducts are often treated with cemented soils compacted in a swedge to provide a smooth transition between a flexible foundation (as a soil embankment) and rigid structures like bridges or viaducts generally founded on piles. In this case, the smooth stiffness transition is implemented by using CSM columns whose length is maximum near the bridge/viaduct abutment and decreases as the distance to the abutment increases.

Having defined the type of geotechnical construction to be analysed by the carbon calculator, the different emission sources identified above should be conveniently quantified. Being materials the source which represents the larger portion of $\mathrm{CO}_{2}$ it was decided to keep the other sources constant and analyse three different materials as described below. This allowed a comparison between different solutions for the binder used in the CSM columns. 
The quantities of each material were therefore calculated in detail and introduced in the carbon calculator, while standard values were assumed for the other sources which were kept constant in the three analysis.

\section{Materials description}

The following binders were considered in this work:

- $\quad$ Ordinary Portland cement (OPC) without main additions also named as CEM I by ASTM C 150 (2004);

- $\quad$ Blast furnace low-heat/sulfate-resistant cement CEM III/B 32,5 (EN 197, 2000);

- $\quad$ Geopolymeric binder made by the alkaline activation (AA) of fly ash;

The first two materials are recommended by Bauer (2004) as adequate for CSM works, the third is a new binder commonly associated with a low carbon emission (TURNER; COLINS, 2013). In fact, while OPC production is responsible for emission the almost 1 ton of $\mathrm{CO}_{2}$ per ton of OPC produced, AA uses a waste by-product from thermoelectric power plants (fly ash).

Blast furnace cement is created through the addition of granulated blast furnace slag (GGbs) with Portland cement clinker and gypsum reducing the amount of Portland cement clincker that generates such amount of $\mathrm{CO}_{2}$ emissons. Blast furnace slag is a byproduct of the iron and steel manufacturing process. In the production of steel, iron ore - a mixture of oxides of iron, silica, and alumina - together with a fuel consisting of coke, natural gas, oxygen and pulverised coal and also limestone as a fluxing agent, are fed into a blast furnace, which consists of a large vertical chamber through which large volumes of hot air are blasted. Generally a blast furnace operates on a continuous basis and produces approximately 250 $300 \mathrm{~kg}$ of slag/ton of iron produced (worldcement.com). In the particular case of CEM III/B, there are $27 \%$ of Portland cement and $73 \%$ of GGbs, which substancially reduces its carbon footprint.

Geopolymers are inorganic polymeric materials, as defined by Davidovits (1991), created by the chemical reaction between alumino-silicate oxides and alkali metal silicate solutions under highly alkaline conditions yielding amorphous to semi-crystalline three dimensional polymeric structures ( $\mathrm{Si}-\mathrm{O}-\mathrm{Al}$ bonds). The most proposed mechanism for geopolymerisation includes (E.G.; XU; VAN DEVENTER, 2000): (i) dissolution of Si and Al 
from the solid aluminosilicate (in this case, fly ash) under strong alkaline solution; (ii) gelation or formation of geopolymers precursors of Si-O-Si and/or Si-O-Al type; (iii) polycondensation of the percursors to form a three-dimensional aluminosilicate framework; (iv) bonding of undissolved solid particles and hardening into a solid structure. This binder has been recently studied for soil improvements works as described in Cristelo et al. (2011) and Rios et al. (2015).

\section{Geometric and mixture properties}

In this study it was assumed two transitions wedges in each side of the bridge in a length of $30 \mathrm{~m}$ and $20 \mathrm{~m}$ of width, resulting in $1200 \mathrm{~m}^{2}$ of treated area. The columns disposed in quadratic mesh of $3.5 \mathrm{~m}$ have an average length of $6 \mathrm{~m}$ which corresponds to $600 \mathrm{~m}$ of columns. In Table 1 the geometric data of the columns is presented where a standard CSM equipment was considered.

Table 1 - Geometric properties

\begin{tabular}{|l|c|}
\hline Surface area occupied by the two transition wedge & $1200 \mathrm{~m}^{2}$ \\
\hline Distance between columns (quadratic mesh) & $3,5 \mathrm{~m}$ \\
\hline Number of columns & 100 \\
\hline Average column length & $6 \mathrm{~m}$ \\
\hline Column dimensions (BCM5 from Bauer) & $2,4 \times 0,55 \mathrm{~m}$ \\
\hline Total column length & $600 \mathrm{~m}$ \\
\hline Total column volume & $792 \mathrm{~m}^{3}$ \\
\hline
\end{tabular}

In the three projects, it was considered $0,4 \mathrm{~m}^{3}$ of grout per $\mathrm{m}^{3}$ of treated soil. The properties of the grouts are indicated in Table 2. The properties of the geopolymeric binder were obtained from the G8 mixture of Cristelo et al. (2013).

Table 2 - Mixture properties

\begin{tabular}{|c|c|}
\hline CEM I and CEM III/B binders & Geopolymeric binder \\
\hline Water/cement ratio $=1$ & Activator/ash $=0,82$ \\
\hline $300 \mathrm{~kg}$ of cement per $\mathrm{m}^{3}$ of treated soil & $\begin{array}{c}\text { Sodium silicate/sodium hydroxide }=0,5 \\
\text { Total amount of cement }=237,6 \text { ton }\end{array}$ \\
\hline Total amount of water $=237,6$ ton & Concentration of sodium hydroxide $=12,5$ \\
\hline
\end{tabular}


The other information required by the carbon calculator is similar for the three solutions so it will not influence the comparison of footprints between solutions. For that reason, data related to the location and respective distances of transport, equipments, wastes, people, etc... are not detailed in this paper.

\section{Results and discussion}

In agreement with most geotechnical techniques available in the carbon calculator, in the case studied in this paper the most important emission source is materials, followed by energy with a much lower contribution, as presented in Figure 1 for the CEM I solution although similar distributions were also found for the other two binders. As a consequence, according to the classification indicated above, only materials and energy are considered primary emission sources, while the others are secondary with less than $5 \%$ of contribution to the global carbon footprint. This highlights the importance of studying $\mathrm{CO}_{2}$ emissions of different material solutions available for the same geotechnical technique.

Figure 1- Total carbon footprint divided by the different emission sources evaluated by the carbon calculator (CEM I

case)

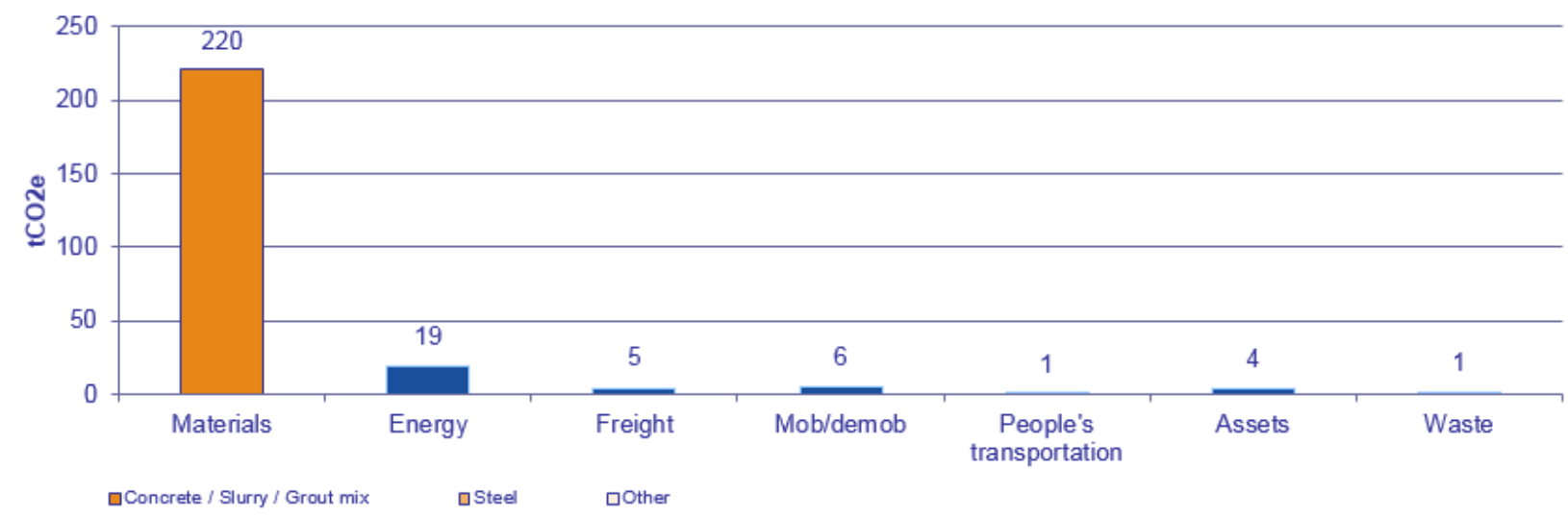

Figure 2 shows the comparison of the total carbon footprint obtained in the CSM technique using different binders. The ordinary Portland cement (CEM I) is the most pollutant material while CEM III is the most environmental friendly solution with 100 tons of $\mathrm{CO}_{2} \mathrm{eq}$. 
The use of geopolymeric binder allows a significant reduction in the carbon footprint, when compared to the traditional option, with an intermediate amount of $\mathrm{CO}_{2}$ eq between the two types of cements.

Figure 2 - Total carbon footprint obtained in CSM technique using different binders

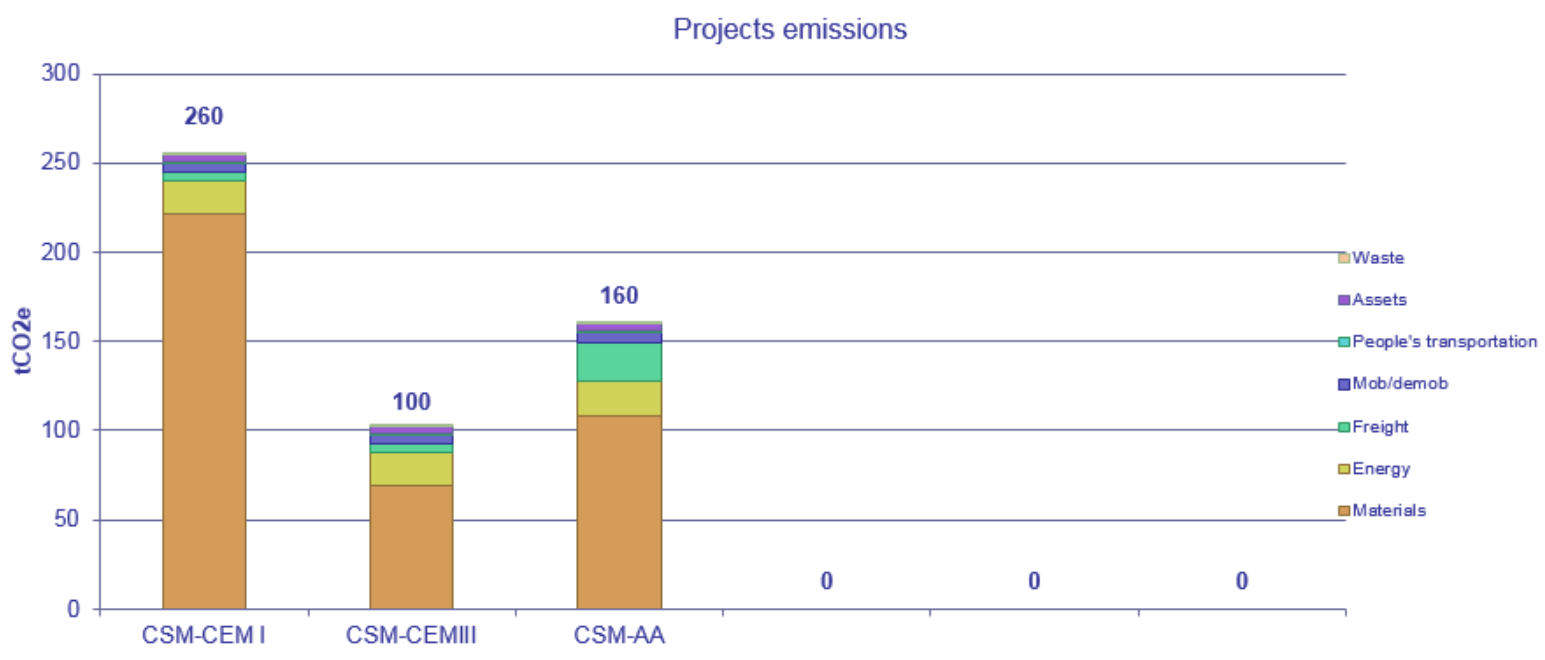

Finally, Figure 3 presents the comparison of the carbon footprint per project cost, to analyse the cost/benefit ratio of each material. For that purpose the costs assumed for each material are the ones explained in Table 3.

Figure 3 - Total carbon footprint per project cost obtained in CSM technique using different binders

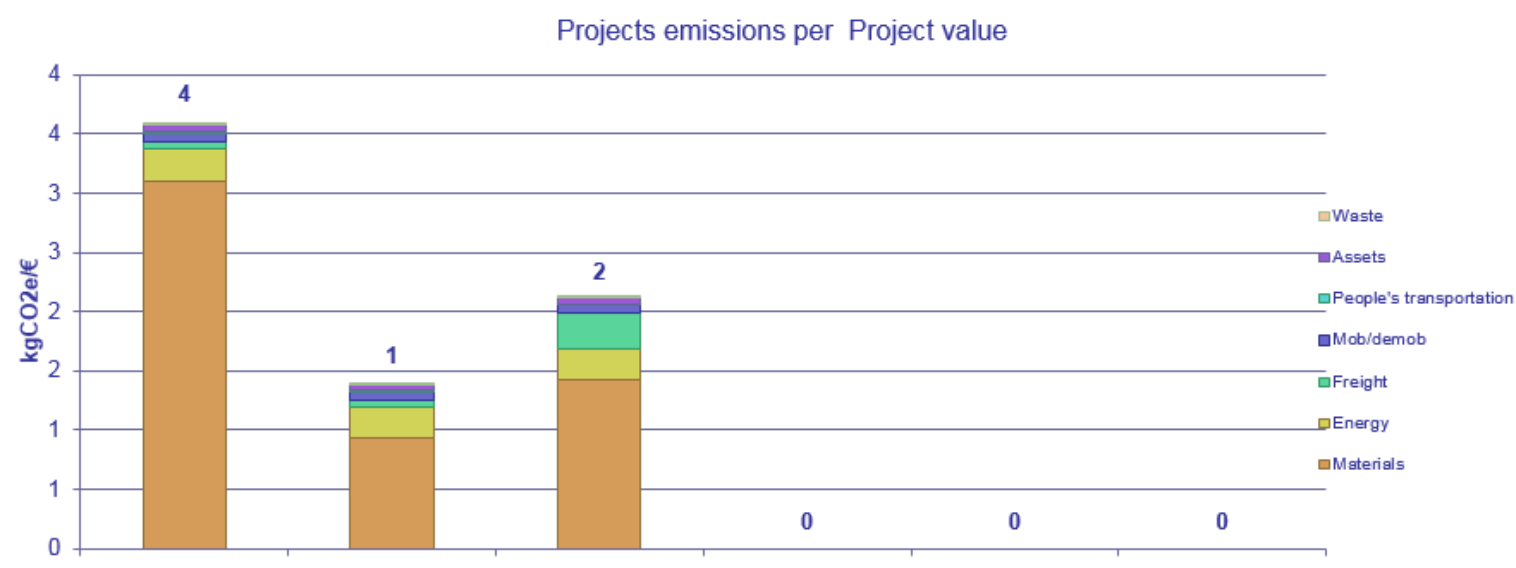


Table 3: Material costs

\begin{tabular}{|c|c|c|}
\hline CEM I binder & CEM III/B binder & Geopolymeric binder \\
\hline $71232 €$ & $73608 €$ & $75431 €$ \\
\hline
\end{tabular}

\section{Conclusions and further research}

OP cement, blast furnace slag cement and alkali activated fly ash were used to improve the mechanical behaviour of transition wedge, through cutter-soil mixing columns. The financial analysis showed that the cement-based solutions are more advantageous. However, it should be noted that the application of alkali activation to soil improvement is still at an early stage, i.e. it is not fully optimised. For instance, the use of industrial waste as the main activator component is being addressed by several research teams, which would significantly decrease the financial and environmental cost of this solution.

A thorough assessment of the mechanical performance of each type of binder should be carried out, as well as a financial and environmental assessment of their respective applications in different techniques, like jet grouting or deep mixing columns.

The main conclusion from the presented results is that the alkali activated ash grout is already competitive, at such an early stage of its development, with traditional cementbased grouts. Also significant is the capacity of this new carbon calculator tool to quantify and help defyning, based on solid and supported argumentation, the ups and downs of any binder and/or technique to be used in geotechnical works.

Acknowledgments: The authors would like to acknowledge the company Pegop - Energia Eléctrica SA which runs the thermoelectric power plant of Pego, for the supply of fly ash, and the MCTES/FCT (Portuguese Science and Technology Foundation of Portuguese Ministry of Science and Technology) for their financial support through the SFRH/BPD/85863/2012 scholarship, which is co-funded by the European Social Fund by POCH program.

\section{REFERENCES}

ASTM C 150 - (2004). Standard Specification for Portland Cement. Americal Society for Testing Materials, United States. 2004. 
CRISTELO, N.; GLENDINNING, S.; Pinto, A. T. Deep soft soil improvement by alkaline activation. Ground Improvement 164(GI2): p. 73-82, 2011.

CRISTELO, N.; SOARES, E.; ROSA, I.; MIRANDA, T.; OLIVEIRA, D.; SILVA, R. A.; CHAVES, A. Rheological properties of alkaline activated fly ash used in jet grouting applications. Construction and Building Materials, No.48, p. 925-933, 2013.

DAVIDOVITS, J. Geopolymers - Inorganic polymeric new materials. Journal of Thermal Analysis, No.37, p. 1633-1656, 1991.

LEMAIGNAN; WILMOTTE. EFFC DFI Carbon Calculator Methodological and User

Guide V 2.0, Carbone4 (www.carbone4.com). 2013.

RIOS, S.; CRISTELO, C.; FONSECA, A. V. da; FERREIRA, C. Structural Performance of Alkali Activated Soil-Ash versus Soil-Cement. Journal of Materials in Civil Engineering DOI: 10.1061/(ASCE)MT.1943-5533.0001398. 2015.

TURNER, L. K.; COLLINS, F. G. Carbon dioxide equivalent (CO2-e) emissions: A comparison between geopolymer and OPC cement concrete. Construction and Building Materials, No. 43, p. 125-130, 2013.

WORLDCEMENT.com:

<http://www.worldcement.com/europe/cis/09072012/Benefits_of_blastfurnace_cement_1159/ $>$. Accessed on 9/3/2015.

XU, H.; VAN DEVENTER, J. S. J. The geopolymerisation of alumino-silicate minerals. International Journal of Mineral Processes, No.59, p. 247-266, 2000.

Recebimento dos originais: 04/08/2015

Aceitação para publicação: 03/11/2015 